which was also a confirmation of one granted by his father, and on the following day he granted a similar confirmation to the men of Romney : but both these earlier charters are lost. But the most noteworthy point in all these charters is that in the charter to the men of Lydd and Dengemarsh is a clause that they should be quit of toll, \&c., ' sicut quieti esse debent ex consuetudine quinque portuum,' a statement which affords written evidence of the existence of the confederation thirty-three years before the earliest written evidence known to either Mr. Round ${ }^{3}$ or M. Petit-Dutaillis. ${ }^{4}$ All that Mr. Round says of John's charters to the individual ports may be said of the charters of Henry II. In passing, it may be noticed that on the same 26 July 1313, Edward II confirmed a charter granted by John in 1207 to the barons of Pevensey.

A. BaLlard.

\title{
An Assessment for the Fortieth of $\mathrm{I}^{2} 3^{2}$.
}

Is September 1232, when Peter des Roches had just become the chief adviser of Henry III, an aid of a fortieth of movables was granted by an assembly at Lambeth. ${ }^{1}$ The grant was to be appropriated to the payment of the king's debt to the count of Brittany. ${ }^{8}$ The enrolment of the writ of collection is to be found on the Close Roll ; ${ }^{3}$ and part of a roll of assessment made before the commissioners survives among the Rentals and Surveys at the Public Record Office. This document, a fragment of a longer roll, deals with the vill of Stathern (Leicestershire), which belonged partly to the fee of William de Albini, lord of Belvoir, ${ }^{4}$ and partly to the priory of Belvoir." The roll begins in the middle of the Albini fee and ends with the tenants of the priory. The assessment of the fortieth is exact in 16 cases; in one the assessment is too high by the twentieth part of a penny; and in the remaining eight cases, the sum is worked out to the nearest fraction of a mark, 68. $4 d$. for example being treated as $68.8 d$.

N. NIEMEYer.

\section{[Rentals \& Surveys, Gen. Ser., Roll 531.]}

Robertus Sarninge (?) Bladum suum valuit ${ }^{6} 21$ solidos et 4 denarios. Duos equos habuit et valuerunt $6 \mathrm{~s}$. Tres vaccas et valuerunt $8 \mathrm{~s}^{7}$ Summa 3 marcae. Domino Regi 12 à.

3 Feudal England, p. 564.

- Studies stupplementary to Stubbs' Constitutional History, p. 87.

' Matth. Paris, Chron. Mai. iii. 223.

2 Ibid. For notices of the collection compare Amnal. Monast. ii. 310; iii. 72-3; iv. 423.

- Cal. of Close Rolls, 1231-4, p. 155.

+ Nichols, Hist. and Antiq. of Leic. Ir. pt. i. p. 355. s Monast. Angl. iii. 285.

- The assessment was made on chattels as they were held on 22 Sept. 1232; 'quadragesimam partem . . mobilium . . sicut es babuerunt in crastino saneti Miatthaei anno regni nostri xvio': Cal. of Close Rolls 1231-4, p. 155.

'The 'mobilia' are enumerated in the writ : 'videlicet de bladis, carrucis, ovibus, raccis, porcis, haraciis, equis carottariis et depatatis ad wainagium in maneriis,' $i b i d$. None of the men of Stathern possessed all these things. 
Hugo Kaihou Bladum sunm valuit 22 s. et $4 \mathrm{~d}$. Duos equos [habuit et valuerunt] $\theta$ s. Unum bovem et dass vaccas et valuerunt $8 \mathrm{~s}$. Et 15 ores et valuerunt 10 s. Summa 3 marca $[6$ s. 4 d.] Domino Regi $14 \mathrm{~d}$.

Nicholaus Prepositus. Bladum suum valuit 2 marcas. Duos equos habrit et valuerunt 6 s. Duos boves et valuerunt 6 s. Unam vaccam $2 \mathrm{~g}$. 12 oves et valuerant 8 s. Summa 3 marcae 8 s. 8 d. Domino Regi 15 d.

Radulfus de Hoiland. Bladum suum valuit 8 s. 4 d. Et duos boves babuit et valuerunt $5 \mathrm{~s}$. Summa 1 marca. Domino Regi $4 \mathrm{~d}$.

Willelmus Cocus. Bladum suum valuit $10 \mathrm{~s}$. Unum equum habuit et valuit $3 \mathrm{~s}$. Unam vaccam et valuit 2 s. et dimidiam. Summa 1 marca $20 \mathrm{~d}$. Domino Regi 4 d. unum obolum.

Walterus filius (?) Dode. Bledum suum valuit 2 marcas 4 d. Duos equos [habuit et valuerunt] $7 \mathrm{~s}$. Duos boves et duas vaccas et valuerunt [10] s. 24 oves et valuerunt 16 s. Summa 4 marca et dimidia. Domino Regi $18 \mathrm{~d}$.

Hugo filius Nigelli. Bladum suum valuit $20 \mathrm{~s}$. Duos boves babuit et valuerunt $6 \mathrm{~s}$. Duas vaccas et valuerunt $4 \mathrm{~s} .4 \mathrm{~d}$. Unum equam et valuit 2 s. 4 oves et valuerunt 2 s. 8 d. Summa 2 marcae 8 s. Domino Regi $10 \mathrm{~d}$.

Walterus de Hideby. Bladum sunm valuit $20 \mathrm{~s}$. Duos boves et duas vaccas habuit et valuerunt $12 \mathrm{~s} .15$ oves et valuerunt $10 \mathrm{~s}$. Summa 3 marcae 20 d. Domino Regi 12 d. unum obolum.

Dionysius de Hoiland. Bladum suum valuit [9] s. Unum equum habuit et 5 (?) oves et valuerunt $6 \mathrm{~s}$. Summa 1 marca $20 \mathrm{~d}$. Domino Regi [4] d. unum obolum.

Alicia vidua. Bladum suum valuit 1 marcam. Duas vaccas [habnit et valuerunt] 5 s. 3 oves et valuerunt 2 s. Summa 1 marca [7 8.] Domino Regi 6 d.

Galfridus filius Walteri. Bladum sunm valuit 2 marcas. Unum equum habuit et valuit $3 \mathrm{~s}$. Duos boves et duss vaccas et valuerunt $11 \mathrm{~s}$. 8 oves et valuerunt 2 s. Summa 3 marcae 2 s. 8 d. Domino Regi 12 d. unum obolnm.

Robertus Parrus. Bladum suum valuit 1 marcam. Dues vaccas habuit et valuerunt $5 \mathrm{~s}$. 15 oves et valuerunt $10 \mathrm{~s}$. Summa 2 marcae $20 \mathrm{~d}$. Domino Regi $8 \mathrm{~d}$.

Rogerus Bond, Bledum suum valuit 1 marcam. Unum equum habuit et valuit 3 s. Unum bovem et valuit $9 \mathrm{~s}$. Unum ovem et valuit $8 \mathrm{~d}$. Summa $20 \mathrm{~s}$. Domino Regi $6 \mathrm{~d}$.

Willelmus ad Fontem. Bladum suam valuit 1 marcam. Unum bovem habuit et valuit $3 \mathrm{~s}$. Unum equum et valuit $2 \mathrm{~s}$. Tres oves et valuit $2 \mathrm{~s}$. Summa 1 marca et $9 \mathrm{~s}$. Domino Regi $6 \mathrm{~d}$. et tres quadrantes.

Willelmus Sutor. Bladum suum valuit $5 \mathrm{~s}$. Duas vaccas hebuit et valuerunt 5 s. 10 ores et valuerunt dimidiam marcam. Summa $16 \mathrm{~s}$. $8 \mathrm{~d}$. Domino Regi $5 \mathrm{~d}$.

Johannis de A ubeni. Bladum suum valuit 29 s. 8 d. 4 boves et valuerunt $13 \mathrm{~s}$. Duos equos et veluerunt $5 \mathrm{~s}$. Summa 3 marcae $20 \mathrm{~d}$. Domino Regi $12 \mathrm{~d}$. unum obolum.

Giliena Borard. Bladum suum valuit 4 s. Duas vaccas habuit et valuerunt 4 s. 3 oves et valuerunt 2 s. Summa 10 s. Domino Regi $3 \mathrm{~d}$. 
Simon Borard. Bladum suum valuit 6 s. 20 d. Une genie $\theta^{8}$ et valuit 2 s. 8 oves et valuerunt 2 e. Summa 11 s. 8 d. Domino Regi 8 d. unum obolum.

Walterus de Aubeni. Blgdum suum valuit $14 \mathrm{~s}$. Duos boves habet et valuerunt $6 \mathrm{~s}$. Summe $20 \mathrm{~s}$. Domino Regi $6 \mathrm{~d}$.

Robertus frater Nicolai. Bladum suum valuit 3 s. 8 d. Une genice ${ }^{8}$ et valnit $20 \mathrm{~d}$. 2 oves et valuerunt $16 \mathrm{~d}$. Summa dimidia marca. Domino Regi $2 \mathrm{~d}$.

Robertus filius Walteri. Bladum suum valuit 2 marcas. 8 boves habuit et valuerunt $10 \mathrm{~s}$. Duas vaccas et valuerunt $4 \mathrm{~s}$. 6 d. Duos equos et valuerunt $6 \mathrm{~s}$. 15 oves et valuerunt $10 \mathrm{~s}$. Summa 4 marcae $40 \mathrm{~d}$. Domino Regi $17 \mathrm{~d}$.

Hugo Prepositus. Bladum suum valuit $21 \mathrm{~s} . \quad 3$ boves habnit et valuerunt 9 s. Unam vaccam et valuit [8] s. Duos equos et valuerunt 4 s. 12 oves et valuerunt 8 s. Summa 3 marcae 5 s. Domino Regi $18 \mathrm{~d}$. unum obolum.

Ralph Murdoc. Bladum suum valuit $20 \mathrm{~s}$. Duos boves habuit et valuerunt $6 \mathrm{~s}$. Duas vaceas et valuerunt $5 \mathrm{~s}$. Unum equum et valuit 3 s. 15 oves et valuerant 10 s. Summa 3 marcae 4 s. Domino Regi 13 d. unum obolum.

Hii sunt tenentes Prioris de Belvero.

Ricardus Page. Bladum suum valuit $10 \mathrm{~s}$. Unum equum habuit et valuit 3 s. Unum bovem et valuit 3 s. Unam vaccam et valuit $2 \mathrm{~s}$. et dimidium. 5 oves et valuerunt 3 s. 4.d. Summa 21 s. 10 d. Domino Regi $6 \mathrm{~d}$. unum obolum.

Gilbertus Bond. Bladum saum valuit $11 \mathrm{~s}$. Unum bovem habuit et valuit 3 s. Unam vacam et valuit $2 \mathrm{~s}$. Duos equos et valuerunt 5 s. 9 oves et valuerunt 6 s. Summa 2 marcae $4 \mathrm{~d}$. Domino Regi $8 \mathrm{~d}$.

[In dorso.] Summa £36. 14s. de Stakedirin. ${ }^{9}$

Summa quae pertinet ad Regem 18s. $8 \frac{1}{2} d$.

\section{The Oldest Account Book of the University of Oxford.}

THE document here printed, the oldest account book extant of the University of Oxford, is preserved in the university Archives. It consists of six narrow leaves of paper written on both sides, some of them much stained by oak-galls, which were employed to revive faded passages. The use of galls, which has played such havoc with some of the oldest university registers, has fortunately here not wholly obliterated any of the writing. A note at the end of the document states that it was transcribed on 11 August 1703 by William Smith, who adds that he treated it 'infusione gallarum quibusdam in locis prius pallidis.' His transcript is now among the manuscripts of the Society of Antiquaries (MS. 72, i.e. Smith MS. 1, fol. 135).

The accounts record expenses incurred by university officials in connexion with journeys to London from 4 November to the following 17 February, and although the years are nowhere given

'Apparently a 'heifer'; Fr. gerisse, from Lat. iunex. Du Cange gives only the diminative iuricula.

- Stathern. 
it seems clear that they were 1357 and 1358 . This conclusion is based chiefly on the entries which set forth that on 22 January the chancellor, proctors, and others journeyed to London, on business relating to John de Kedyngton, an Augustinian friar. A document in the university Archives (S.E.P., Y. 11) shows that this friar had obtained a citation of the chancellor and proctors, dated 81 December 1357, to appear at the court of the archbishop of Canterbury to justify their action in suspending him from scholastic acts. The citation was repudiated by William, provincial prior of the order, and John, prior, and the convent at Oxford on 21 January 1358, which was the day before the deputation set out for London. ${ }^{1}$ Another clue to the date may be derived from the opening paragraph, which says that the journey was undertaken 'pro una clausula inserenda de novo in carta per dominum nostrum Regem post conflictum Oxonie Universitati concessa,' the commencement of the clause being, 'Et quod clericus mercati.' This clause ${ }^{2}$ occurs in a royal mandate to all justices and ministers of the king to allow the chancellor of the university to enjoy those privileges recently granted to him touching the custody of the assize of bread and ale, of weights and measures, cognisance of forestallers and regrators, \&c. The charter granted to the university after the great conflict with the town in 1355 , which left the former poorer in scholars but richer in privileges, is enrolled on the Charter Roll 29 Edw. III, no. 5 (27 June).

The most important entry in the accounts relates to a dispute between the university and Thomas de Langeley, who, as one of the king's justices appointed to inquire concerning the enforcement of the statute of labourers, ${ }^{3}$ had cited men of the town of Oxford to appear before him at Woodstock. As the chancellor of the university and the mayor of Oxford had been appointed justices for the town of Oxford in March 1857, ${ }^{4}$ the action of Thomes de Langeley was clearly ultra rires. The text of the accounts is rather obscure, but it is evident that John de Burton and his colleagues were successful in obtaining a writ of prohibition against the king's justiciar. That most of the other entries are domestic in character need not perhaps, in this particular instance, be greatly deplored, since details concerning the everyday life of university officials as early as the fourteenth century are necessarily almost unknown.

Stricklixd Grbson.

1 The witnesses to this docament are Willelmus de Alneto, Richardus, abbas de Parco Lude, Iohannes Modi, Kicardus de Tenummatha, Galfridus de Sancto Bciulph, Iohannes Bourton, Iohannes Bernewike.

= 'Et quod clericus mercati se in presentia nostra vel heredum nostrorum decetero non intromittat infra burgam illum aut suburbia einsdem de officio illo exercendo de aliqua re eundem burgum vel suburbia tangente' (Pat. Roll 32 Edr. III, p. 2, w. 3 (10 Januars): Reg. Priv. Univ. Oxon. p. 37).

- Close Roll 32 Edw. III, m. 23 (24 April).

+ Pat. Roll 31 Edw. III, p. 1, M. 19 d. 
Fol. 1r. Expense Iohannis de Burton versus London eundo ibidem commorando et redeundo pro vna clausula inserenda de nouo in carta per dominum nostrum Regem post conflictum Oxon vninersitati concessa et pro litteris de priuato sigillo dictam clausalam confirmando ad Cancellarium Anglie directis cuias clausule tenor talis est Et quod clericus mercati ... In primis iij die mensis Nouembris in expensis suis pro se et equo suo per dien ei noctem $x \mathrm{xij}^{\mathrm{d}}$

Summa . . . $\mathbf{x i j}^{\mathrm{d}}$

Item $\nabla$ die mensis Nouembris in expensis suis pro se et equo suo per diem et noctem xijd

Summa . . . $\mathbf{x i j}^{\star}$

Item vj die Nouembris in expensis suis et equo per diem et noctem $x i^{d}$

Summa . . . $\mathrm{xij}^{\mathrm{d}}$

Item vij die Nouembris in expensis suis et equo per diem et noctem $\mathrm{xij}^{\mathrm{d}}$

Summa . . . $\mathbf{x i j d}$

Item viij die Nouembris in expensis suis per diem et noctem xij ${ }^{d}$

Summa . . $\quad \mathrm{xij}^{\mathrm{d}}$

Item ix die Nouembris in expensis suis et equo per diem et nootem $\mathrm{xij}^{\mathrm{d}}$

Summa . . . $\mathbf{x i j}^{\mathbf{d}}$

Item x die Nouembris in expensis suis et equo per diem et noctem $x \mathrm{xij}^{\mathrm{d}}$

Summa - . $\quad \mathbf{x i j}^{\mathbf{d}}$

Item $\mathrm{xj}$ die Nonembris in expensis suis et equo per diem et noctem $x$ ij $^{\mathrm{d}}$

Summa

Item xij die Nouembris in expensis suis et equo per diem et noctem $\mathrm{vj}^{\mathrm{d}}$

$$
\begin{aligned}
& \text { Summa Totalis . . } \mathrm{viij}^{\prime} \mathrm{vj}^{\mathrm{a}} \\
& \text { Expense forinsece }
\end{aligned}
$$

Item in allocacione vnius equi per viij dies et dimidium $\mathrm{ij}^{\mathrm{k}} \mathrm{iij}^{\mathrm{d}}$ Item in ferura equi iij $^{\mathrm{d}}$ Item in litera per totum tempus $j^{\mathrm{d}}$ o Item garcioni pro dicta equi custodia per tempus predictum iijj ${ }^{\mathrm{I}}$ Item in botillagio per dictos viij dies dinersis vicibus versus episcopum Winton Iohannem de Weuelhyke Westm. et eanctum paulum $x v^{d}$ Item apud Westm. in vino pro clericis- $x \mathrm{j}^{\mathrm{l}}$ Item in mites [?] $\mathrm{ijj}^{\mathrm{d}}$ Item pro parte solucionis dicte [?] carte de nouo scribende vjs viijd

$$
\text { Summa totaiis . . } \mathrm{xij}^{*} \mathrm{ij}^{\mathrm{d}} \mathrm{o} \text {. }
$$

Summa Totalis vtriusque partis diete et forinsec. per dictos viij.dies cum dimidio $\mathrm{xx}^{\mathrm{j}} \mathrm{ij}^{\mathrm{d}} \mathrm{o}$. Item petit $\mathrm{vij}^{\mathrm{d}}$ qui sunt a retro de vltimo compoto

Summa vija

$$
\text { Summa totalis }
$$

Expensis factis per Iohannem de Burton versus London eundo ibidem commorando et redeundo pro breuibus sicut alias impetrandis ad dominum Thomam de Langelie et socios suos sedentes apud Wodestoke ${ }^{3}$ de mensuris et ponderibus de operariis

\section{- Woodstock.}

VOL. XXIV.-NO. XCVI. 
artificibus ot aliis privilegiis anullandis super hominibas ville Oxon coram eis ibidem extra dictam villam trahendo ${ }^{b}$ gontra privilegis vninersitatis et optinuit brene ita cessio ${ }^{7}$ dictorum domini Thome et sociorum suorum non hsbuit locum In primis $x$ die Ianuarii apud Tedlesworth ${ }^{8}$ in pane 0 . Item in ceruisia 0 . Item in coquina $i^{d}$ Item in equo o. Item apud Wycombe pro se et equo iijil Item apud Woxebrigge ${ }^{\theta}$ per noctem in pane 0 . Item in ceruisia $j^{d}$ Item in coquina ij $^{d}$ Item in loctis $i^{d}$ Item in candelis $\mathrm{q}^{2}$ Item in feno $\mathrm{i}^{\mathrm{d}}$ Item in prebenda ij $^{\mathrm{d}}$ Item in focali $o$. Summa . . $x v^{\mathrm{d}}$ o. $q^{2}$

Item xj die Ianuarii apud Aketonum ${ }^{10} \mathrm{i}^{\mathrm{d}}$ Item eodem die et nocte London $\mathbf{x i i j}^{\mathrm{d}} \mathbf{o}$.

Summs . . xiiij 0 .

tol. 2* Item xij die Isnuarii London pro se et equo suo in expensis ibidem $x v^{2}$ Summa . . . $x v^{d}$

Item xiij die Irnusrii Irondon pro se et equo suo in expensis ibidem xiiijd

Summa . . . xiiij

Item xiiij die London pro se et equo suo in expensis ibidem $x^{d}$ Item eadem nocte equitando oum ij hominibus de London versus Woxebrigge pro festinacione breuium noctanter alias non haberent looum in expensis eorundem tractando [?] cum tribus equis in illa noote $\mathrm{ij}^{\bullet} \mathrm{iij}^{\mathrm{d}} 0 .{ }^{11}$

Summa . . iii' ido.

Item xv die mane apud Wycombe ad iantacula dictorum xiijd Item apud Tedlesworth $\nabla^{d}$

$$
\begin{aligned}
& \text { Summa xviij } \\
& \text { Summa diate } \\
& \text {. ix viijd } 0 .
\end{aligned}
$$

\section{Expense forinsece}

In primis pro vno magno breue recitante cartam et ij aliis breuibus directis Thome de Langele et sociis suis et altero directo in screcario ij" Item in vno conducto xxij ${ }^{d}$ Item in botillagio ibidem per totum tempus viij ${ }^{d}$ Item in ferura equi $\mathrm{ij}^{d}$ o. Item vni garcioni pro oustodia equorum per totum tempus $\mathrm{ij}^{\mathrm{d}}$ Item in leotis $j^{\mathrm{d}}$

Summa totalis forinsec. iijja $^{\mathrm{d}} \mathrm{x}^{\mathrm{d}} \mathrm{o}$.

Summs totalis diete et forinsec. per dictos dies ibidem eundo et redeundo

Expensis factis per Cancellarium et procuratores ${ }^{1 y}$ cum dominis et magistria Ricardo ${ }^{13}$ abbate de parco lude Iohanne de Lancastre et aliis clericis videlicet in toto $x \mathbf{x}$ homines preter supernenientes et svj equos versus Lrondon eundo ibidem commorando et redeundo pro negociis vniuersitatis tangentibus Magistrum Iohannem de Kedyngton doctorem in Theologia in domo fratrum Auguetin. ensium et aliis multis negociis expediendis

- For trahendis.

- Tetaworth.

11 This entry is partly obliterated in the ISS.

12 John de Hodum or Botham, John Joskin, Alerander de Feribrigge.

"See Victoria County Hist., Lincolnshire, ii. 141.
- For sessio.

10 Acton. 
In primis apad Wycombe xxij die mensis Ianuarii in pane $x^{d} 0$. Summa [?] in iij lagenis vini $\mathrm{ij}^{\prime} \mathrm{vj}^{\mathrm{d}}$ Item in vij lagenis ceruisio xiiijd Coquina in grossis carnibus $\mathbf{x x}^{\mathrm{d}}$ o. Item in iij cuniculis $\mathrm{xij}^{\mathrm{d}}$ Item in iij perdicibus $x^{d}$ o. Item in paruis volucribus emptis iiijd in focali viijd Itom in candelis iij ${ }^{d} o$. Item in lectis vijd Garcioni feno pro xvj equis $x \mathrm{vj}^{\mathrm{d}}$ Item in iij bussellis anene et $j$ dimidio bz. ij* Item in pane pro eisdem equis ix $x^{d}$ o. Item in ferura $\nabla^{d}$ o. Item solutum Adam camerario cancellarii pro $j$ lagena ceruisie querenti in villa ij $^{\mathrm{d}}$ Summa . . . xv

Item sxiij die Ianuarii apud Woxebrigge in pane $\mathrm{vi}^{\mathrm{d}}$ o. Item in ceruisia viijd Item in orrnibus $x \mathrm{jij}^{\mathrm{d}} \mathrm{o}$. Item in pene pro equo $\mathrm{xv}^{\mathrm{d}}$ Item in feno $\mathrm{ij}^{\mathrm{d}}$ Item in ferura $\mathrm{vij}^{\mathrm{d}}$ o. Item eodem die apud Aketon in cervisia $\mathrm{ij}^{\mathrm{d}} \mathrm{o}$. Itom eodem die London ad cenam in pane viij" $o$. in vj lagenis ceruisie xij d ${ }^{d}$ tem in ij lagenis vini $x v^{d}$ Item in grossis carnibus emptis $x$ xijj $^{\mathrm{d}}$ Item in ij cunioulis vijd Item in ij perdicibas viijd Item in sale et farina auene $i^{d} 0$. Item in focali ix ${ }^{\mathrm{d}}$ Item in $\mathrm{j}^{\mathrm{ll}}$ et dimidio candelarum $\mathrm{v}^{\mathrm{d}}$ Item in feno pro xvj equis per dictum diem et noctem ij" viij ${ }^{\star}$ Item in iij busellis suene ij" Item in pane pro eisdem iiijd Item in leotis viij ${ }^{\mathrm{d}}$ Item in capistris $\mathrm{ij}^{\mathrm{d}}$ Item in croco $\mathrm{j}^{\mathrm{d}}$ Item in aqua 0.

$$
\text { Summa . . xviije } 0 .
$$

Item xxiiij die Isnuarii London in pane $x v^{d}$ Item in ceruisia $x$ jid $^{d}$ Item in vino $8 x^{\mathrm{d}}$ Item in grossis carnibus $\mathbf{x} \mathrm{j}^{\mathrm{d}}$ Item in cuniculis viij ${ }^{\alpha}$ Item in $j$ plouer iiij ${ }^{d}$ Item in paruis volucribus $x^{\text {xij }}{ }^{\text {Item in pies }} \mathbf{x x}^{\mathrm{d}}$ Item in $\mathrm{j}$ pike [?] $\mathbf{x x}^{\mathrm{d}}$ Item in roch iiijd Item in smelt iiijd Item in onis $\mathrm{jd}^{\mathrm{d}}$ Item in pipere et croco $\mathrm{ijj}^{\mathrm{d}}$ Item in selsea $j^{d}$ Item in oystres et sepis iiijd Item in focali vijd Item in oandelis iijd Item in feno pro $x$ j j equis per diem et noctem in grossis iij" Itom in iij busellis anene ij" Item in pane pro eisdem post aquam $i x^{d}$ Item in lectis viijd Item in ferura $i j^{d}$

Summa - . $\mathbf{x x i}^{\mathrm{i}} \mathrm{iij}^{\mathrm{d}} \mathrm{o}$.

Item eodem die in expensis forinsecis in botillagio $\mathrm{ij}$. Item in sotalaribas garcionibus videlicet Willelmo coquo et garcioni seneschalli et abbatis Osneye et garcioni cancellarii ij*

Summa · . . iiij»

Item $x \times \nabla$ die Ianuarii London in pane vijd ${ }^{d}$ tem in ceruisia $x^{d}$ Item in vino $x \mathrm{ij}^{\mathrm{d}}$ Item in grossis carnibus $\mathrm{xj}^{\mathrm{d}}$ Item in $\mathrm{j}$ proicio [?] iiijd Item in focali $\mathrm{vj}^{\mathrm{d}}$ Item in candela $\mathrm{ij}^{\mathrm{d}} \mathrm{o}$. Item in lectis viij ${ }^{\mathrm{d}}$ Item in feno pro equis iijs Item in prebenda $\mathrm{ij}^{\mathrm{s}}$ Item in pane pro isdem xijd Item in carnibus ad cenam vij ${ }^{d} o$. Item in croco et pipere $\mathrm{ij}^{\mathrm{d}}$ in aqua $\mathrm{j}^{\mathrm{d}}$ pro ij diebus. Item in farrina et sale $\mathrm{j}^{\mathrm{d}}$ Item in botillagio $\mathrm{ij}^{\mathrm{d}}$

Summa

$x^{* i j j^{\bullet}} \mathrm{ij}^{\mathrm{d}}$

Item xxvj die Iannarii London in pane ix ${ }^{d}$ Item in cernisia xiijjd Item in vino $\mathrm{svj}^{d}$ Item in oystres $\mathrm{vj}^{\mathrm{d}}$ Item in alleciis rubeis et albis viij d Item in merlynge et gurnarde xriijd Item in muskeles $\mathrm{ij}^{\prime}$ Item in piris $\mathrm{ijj}^{\mathrm{d}}$ Item in pulueribus et croco $\mathrm{iij}^{\mathrm{d}}$ 
Item in smelt iij" Item in feno iijs $\mathrm{ix}^{\mathrm{d}}$ Item in prebenda auene $\mathrm{xvj}^{1}$ Item in pane pro eisdem $x \mathrm{ijd}^{\mathrm{d}} \mathrm{o}$. Item in focali vij ${ }^{\mathrm{d}}$ Item in lectis vij" Item in candelis iijd Item in vino acri [?] o. Item in botillagio $\mathrm{xij}^{\mathrm{d}}$ Item in litera iij $^{\mathrm{d}}$ Item vni garcioni pro auxilio coqui $\mathrm{j}^{\mathrm{d}}$ Item in ferrure $\mathrm{j}^{\mathrm{jt}} \mathrm{o}$.

Summa . . $x \mathrm{rja}^{\mathrm{j}} \mathrm{ij} \mathrm{j}^{\mathrm{d}} \mathrm{o}$.

fol 8v Item xxvij die Ianuarii London in pane empto viji" Item in vino $x^{\prime \prime}$ Item in cernisia $\mathrm{xj}^{\mathrm{d}}$ Item in salso pisce et duro xiiij ${ }^{1}$ Item in conger $\mathrm{xj}^{\mathrm{d}}$ Item in salmone $\mathrm{ij}^{\prime \prime}$ Item in alleciis $\mathrm{ijj}^{\mathrm{d}}$ Item in focali vij ${ }^{\mathrm{d}}$ Item in candelis $\mathrm{iij}^{\mathrm{d}} \mathrm{o}$. Item in lectis viij"

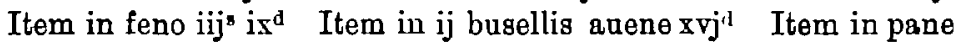
pro eisdem xix ${ }^{d}$ Item in litera $i^{\prime \prime}$ Item in ferrura ante recessum London In equis Cancellarii et procuratorum xj ${ }^{d}$ Item in ferura equorum Lancastre iiij ${ }^{d}$ Item in ferura Abbatis equorum et aliorum vijd $o$.

Summa . . $\mathrm{x}^{\mathrm{s}} \mathrm{iij}^{\mathrm{l}} \mathrm{o}$.

Item xxviij die Ianuarii London ad iantacula ante recessum dominorum versus $O x o n$ in pane $\mathrm{vj}^{\prime \prime} \mathrm{o}$. Item in vino viij ${ }^{\mathrm{d}}$ Item in ceruisia $\mathrm{vj}^{\mathrm{d}} \mathrm{o}$. Item in pies $\mathrm{xix}^{d}$ Item in carnibus pro garcionibus emptis $v^{d}$ Item eodem die ibidem in pane pro equis ante recessum de London $x v^{d}$ Item in feno ante recessum $\mathrm{j}^{\mathrm{d}}$ Item eodem die apud Woxebrigge in pane iiji Item in i potello vini empto $\nabla^{d}$ Item in ceruisia vj" Item in carnibus vj" Item Magistria Galfrido et Henrico Wytefelde 14 pro expensis suis in alio loco et ferura equorum $\mathrm{vj}^{\mathrm{j}} \mathrm{o}$. Item in feno pro equis $\mathrm{j}^{\mathrm{d}} \mathrm{o}$. Item in pane pro eisdem $x v^{d}$ Item eodem die cero ${ }^{15}$ apud Wycombe in pane vij $^{d}$ Item in vino $v^{d}$ Item in ceruisia $x$ j $^{d}$ Item in coquina in grossis carnibus emptis $x$ viij ${ }^{d}$ Item in ij perdicibus vij ${ }^{d}$ Item in ij cuniculis viijd ${ }^{\mathrm{d}}$ Item in focali viij ${ }^{\mathrm{d}}$ Item in lectis viijd Item in candelis iiijd Item in feno pro xvj equis xviij ${ }^{d}$ Item in iij busellis auene pro eisdem ijs Item in pane pro eisdem $\mathbf{I} \mathbf{V}^{\mathrm{d}}$

Summa . $\quad \mathrm{xx}^{3} \mathrm{rij}^{\mathrm{d}}$

Item xxix die Ianuarii apud Tedlesworth in pane empto ijil o. Item in ceruisia iiij ${ }^{\mathrm{d}}$. Item in coquina viij $\mathrm{d}^{\mathrm{d}}$ pane pro equis siij.

Summs $\cdot \cdot \mathrm{ij}^{\mathbf{1}} \mathrm{v}^{\mathrm{d}}$

fol. 4 r

Expense forinsece per dictum tempus

In primis in iij equis allocatis per viij dies predictos ix $^{s}$ viija Item garcioni abbatis de Oseney $\mathrm{vj}^{\mathrm{d}}$ Item garcioni magistri Iohannis ${ }^{\mathrm{it}}$ seneschalli Oxon $\mathrm{vj}^{\mathrm{d}}$ Item famulo galfridi Botilston viij ${ }^{\mathrm{d}}$ Item famulo procuratorum xviij ${ }^{d}$ Item famulo Abbatis $\mathrm{vj}^{\mathrm{d}}$

Summa . . xijs iij d $^{d}$

Totalis . . Summa totalis diete et forinsec . vj" $\mathrm{xix}^{\mathbf{2}} \mathrm{vj}^{\mathrm{j}}$

Item petit pro vno equo conducto versus Bristoll cum domino Cancellario $\mathrm{ij}^{\mathrm{s}}$ Item in vno equo conducto versus Wodestoke cum

14 Probably the fature Prorost of Queen's College.

1) For sero. 
breuibus domino Thome de Langelye et sociis suis directis pro privilegiis vniuersitatis iij $^{\mathrm{d}}$

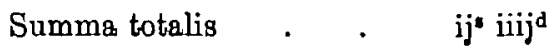

Expense domini Cancellarii et procuratorum vniuersitatis Oxon et fol. $\mathbf{4}^{\top}$ aliorum quinque cum viij equis versus London eundo ibidem et redeundo ad parliamentum ${ }^{17}$ pro negociis vninersitatis.

In primis xj die Februarii apud Tedlesworth in pane $j^{d} 0$. Item in ceruisia $\mathrm{jj}^{\mathrm{d}}$ Item in coquina $\mathrm{ij}^{\mathrm{d}}$ Item in pane pro equis $\mathrm{vij}^{\mathrm{d}}$ Item eodem die cero ${ }^{18}$ apud Wycombe in pane iiij ${ }^{\mathrm{d}}$ Item in ceruisia $\nabla^{d}$ Item in vino $j$ lagena $x^{d}$ Item in carnibus grossis $v^{d}$ Item in iij gallinis xiij ${ }^{d}$. Item in $j$ perdice empto $v^{d}$ Item in $j$ cuniculo $v^{d}$ Item in lectis iiij ${ }^{d}$ Item in feno pro equis vij Item in ij busellis auene $\mathrm{xpj}^{\mathrm{j}}$ Item in pane pro eisdem rij ${ }^{d}$ Item in focali iiij ${ }^{d}$ Item in litera $j^{d}$ Item in ferura iij $^{d} \mathbf{o}$.

$$
\text { Summa . . viij॰ vij } 0 .
$$

Item xij die februarii apad Woxebrigge in pane iijd Item in ceruisia iiij $^{\mathrm{d}} \mathrm{o}$. Item in coquina $\mathrm{v}^{\mathrm{d}}$ Item in pane pro equis vij Item in feno $j^{d}$ Item eodem die apud London in pane $\mathrm{vj}^{\mathrm{d}}$ Item in grossis carnibus s riijd Item in ij gallinis $\mathrm{j}^{\mathrm{d}}$ Item in lectis iiijd Item in candelis $\mathrm{ij}^{\mathrm{d}}$ Item in focali et carbon emptis $\mathrm{vj}^{\mathrm{d}}$ Item in ceruisia $\mathrm{vj}^{\mathrm{d}} \mathrm{o}$. Item in vino viij ${ }^{\mathrm{d}}$ Item in feno pro vij equis $x^{d}{ }^{d}$ o. per diem et noctem. Item in ij busellis auene $x \mathrm{rj}^{\mathrm{d}}$ Item in litera $\mathrm{ij}^{\mathrm{d}}$ Item in pane pro equis $\mathrm{vij}^{\mathrm{d}}$

$$
\text { Summa - . } \quad i x^{8} \times j^{d} 0 .
$$

Item xiij die Februarii London in pane jj $^{\mathrm{d}}$ Item in vino $\mathrm{xij}^{\mathrm{j}}$ Item in ceruisia viij ${ }^{\mathrm{d}}$ Item in grossis carnibus viijd Item in iij gallinis $x \mathrm{xj}^{\mathrm{d}}$ Item in ij capon $\mathrm{xvij}^{\mathrm{d}}$ Item in ij cuniculis $\mathrm{xij}^{\mathrm{d}}$ Item in $\mathrm{ij}^{\mathrm{l}}$ amidol. $\mathrm{v}^{\mathrm{d}}$ Item in pipere puluere et croco iij $\mathrm{d}$. Item salsea $j^{\mathrm{d}}$ Item in ouis $\mathrm{j}^{\mathrm{d}} \mathrm{o}$. Item in feno pro vij equis xiiij $o$. Item in ij busellis auene $x$ j $^{\mathrm{d}}$ Item in pane pro eisdem vij ${ }^{\mathrm{d}}$ Item in litera $\mathrm{j}^{\mathrm{d}}$ Item in focali $\mathrm{jij}^{\mathrm{d}}$ Item in lectis $\mathrm{v}^{\mathrm{d}}$ Item in candelis $\mathrm{ij}^{\mathrm{d}}$ Item in botillagio $\mathrm{ij}^{\mathrm{d}}$ Summa . . . sij" 0 .

Item xiiij die Februarii London in pane $\mathrm{v}^{\mathrm{d}}$ o. Item in vino viij ${ }^{\mathrm{d}}$ Item in ceruisis $\mathrm{vj}^{\mathrm{d}} \mathrm{o}$. Item in oystres $\mathrm{iiij}^{\mathrm{d}}$ Item in muskeles $\mathrm{ij}^{\mathrm{d}}$ Item in alleciis $\mathrm{v}^{\mathrm{d}}$ Item in duro pisce iiijd Item in salso pisce $v^{d}$ Item in roch iijd Item in floundres et plais vijd Itom in pipere et croco et pulueribus $\mathrm{ij}^{\mathrm{d}}$ Item in farrina et sale $\mathrm{ij}$ Item in feno pro vij equis xiijd $o$. Item in prebenda-ij busellis auene $\mathrm{xvj}^{\mathrm{d}}$ Item in pane pro eisdem vij ${ }^{\mathrm{d}}$ Item in litera $\mathrm{j}^{\mathrm{d}}$ Item in ferura $j^{\mathrm{d}}$ Item in lectis $\mathrm{v}^{\mathrm{d}}$ Item in candelis $\mathrm{ij}^{\mathrm{d}}$ Item in focali $\boldsymbol{\nabla}^{\mathrm{d}}$ Summa . . viij $\mathrm{ix}^{\mathrm{d}} \mathbf{0}$.

Item $\mathbf{x \nabla}$ die februarii in pane $\mathrm{vj}^{\mathrm{d}}$ Item in vino $\mathrm{xij}^{\mathrm{d}}$ Item in ceruisia vijd Item in oystres et muskeles vj ${ }^{d}$ Item in alleciis rubeis et albis $\nabla^{\prime}$ Item in anguillis et salsea iiij ${ }^{d}$ Item in smelt iij $^{d}$ Item in duro pisce et salso $\mathrm{j}^{\mathrm{d}}$ Item in merelynge et codelyng : xiij ${ }^{\mathrm{d}}$

17 Parliament of 5 Feb. 1358 ; cf. Parry's Parliaments and Councils, p. 125.

is For sero. 
Item in amidol. $\mathrm{ij}^{\prime \prime} \mathrm{o}$. Item in speciebus et pulnere pro coquina iiij ${ }^{\mathrm{d}}$ Item in ficis et racemis $\mathrm{ij}^{\mathrm{d}}$ Item in piris $\mathrm{ij}^{\mathrm{d}}$ Item in feno pro equis xiijd Item in $\mathrm{ij}$ busellis auene $\mathrm{xvj}^{\mathrm{d}}$ Item in pane vij Item in focali iij ${ }^{\mathrm{d}}$ Item in lectis $\nabla^{\mathrm{d}}$ Item in candelis $\mathrm{ij}^{\mathrm{d}}$

Summa . . . $x^{s} 0$.

Item $x \nabla$ die februarii in pane $\nabla^{d} o$. Item in vino viijd Item in cerrisis $\mathrm{j}^{d}$ Item in oystres iij $^{d}$ Item in alleciis ijd Item in anguillis iiij ${ }^{d}$ Item in smelt jj $^{d}$ Item in gurnard et ray xijd Item in amigdol. $\mathrm{ij}^{\mathrm{d}} \mathrm{o}$. Item in sucura et zinsiberi $\mathrm{ijj}^{\mathrm{d}}$ Item in ficis et racemis iij Item in piris $\mathrm{ij}^{\mathrm{d}}$ Item in feno xiij ${ }^{\mathrm{d}}$ Item in auena $\mathrm{xvj}^{\mathrm{d}}$ Item in pane $\mathrm{vij}^{\mathrm{d}}$ Item [in] focali iiij ${ }^{\mathrm{d}}$ Item in candelis $\mathrm{j}^{\mathrm{d}}$ o. Item in lectis $\mathrm{v}^{\mathrm{d}}$ Item in litera $\mathrm{j}^{\mathrm{d}}$

$$
\text { Summa } \quad . \quad v i j{ }^{*} v^{\mathrm{d}} 0 \text {. }
$$

fol ar Item xvi die februarii in pane $\mathrm{ij}^{\mathrm{d}}$ Item in cernisia iiij ${ }^{\mathrm{d}}$ Item in vino iiij ${ }^{d}$ Item in oystres $j^{d} 0$. Item in salso pisce $\mathrm{ij}^{\mathrm{d}}$ Item in alleciis $j^{d}$ Item in muskales $j^{d}$ Item in smelt $i j^{d}$ Item eodem die apud Woxebrigge in pane $\mathrm{ij}^{d} \mathrm{o}$. Item in vino $\nabla^{d}$ Item in $j$ legena ceruisie empta extra domum iijj pro magistris Item in cervisia pro aliis $\mathrm{j}^{\mathrm{d}} \mathrm{o}$. Item in focali $\mathrm{ij}^{\mathrm{d}}$ Item in pisce $\mathrm{j}^{\mathrm{d}}$ Item in lectis iiij ${ }^{d}$ Item in feno pro equis $v^{d}{ }^{d}$ Item in auena $\mathbf{s v j}^{d}$ Item in pane iiij ${ }^{d}$ Item in litera $\mathrm{j}^{\mathrm{d}}$ Item in ferura London et ibidem videlicet palefrido cancellarii et $\mathrm{jj}$ aliis equis $\mathbf{x}^{\mathrm{d}}$ Item in aliis equis $v^{\mathrm{d}}$ Item in candelis $\mathrm{j}^{\mathrm{d}} \mathrm{o}$.

Summa $\quad . \quad \mathbf{j}^{\prime} \mathbf{x j}^{\mathrm{d}}$

Item xvij die februarii ad prandium apud Wycombe in pane vid $o$. Item in vino $\nabla^{d}$ Item in ceruigia iijd Item in oystres iijd Item in alleciis iij $^{d}$ Item in salso pisce iijd Item in duro pisce frise' $\nabla^{\mathrm{d}}$ o. Item in trotters viij ${ }^{\mathrm{d}}$ Item in lochis et paruis piscibus vij $^{\mathrm{d}}$ Item in sepis ob. Item in feno pro equis $\mathrm{j}^{\mathrm{d}} \mathrm{o}$. Item in pane pro equis vij ${ }^{\mathrm{d}} \quad$ Summa . . iij» viijd

Item $\theta 0$ die apud Tedlesworth in pane $\mathrm{j}^{\mathrm{d}}$ Item in coruisia $\mathrm{ij}^{\mathrm{d}}$ Item in pane pro equis vijd $\mathrm{j}^{\mathrm{d}} \cdot$ Summa . . $\mathbf{x}^{\mathrm{d}}$

fol. Br

\section{Expense forinsece per dictum tempus}

In primis in ij equis allocatis pro procuratoribus iiij viij ${ }^{\mathrm{d}}$ Item in $\mathrm{ij}$ aliis equis allocatis iij" Item in allocacione vnius garcionis per totum tempus $\mathrm{ij}^{2}$ Item pro vno breue in scaccario pro directione

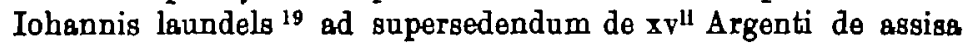
ceruisie quod solutum per prius et alias petunt dictam summam $\mathrm{xij}^{\mathrm{d}}$ Item pro $\mathrm{x}$ breuibus sicut alias ad scaccarium pro baronibus ad deliberandum dictum breue de supersedendo $v^{d}$ Item apud Westm. in vino et piris viij ${ }^{d}$ Item in pane $j^{d}$ Item in emendacione cellarii frenorum et in aliis negociis ix ${ }^{d}$ Item in vno equo

" Sheriff of Oxon and Berks, 1355, P.R.O. Lists and Indexes ix. p. 108. 
conducto pro capellano domini Cancellarii ijs Itom in botillagio per totum tempas $x^{d} \quad$ Summa . . Irja $\mathrm{jj}^{\mathrm{d}}$ Totalis . . Summa totalis istius diete et forinsec. . iiij" $\mathrm{vi}^{\mathrm{N}} \mathrm{xi}^{\mathrm{d}}$ Totalis istius libri Summa

$$
\begin{aligned}
& \text { Summa totalis istius libri. . xiij" iiij" iiijd } q^{2} \\
& \text { [ ] in debito burton . . iijjs vij」 }
\end{aligned}
$$

Summa totalis forinsecarum. Summa infra estimacionem . iij"l iiijs $\mathrm{ij}^{d}$ xiij" iiij"

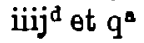

debetur Iohanni de Burton

\section{The Second Council of State during the Commonwealth (1650-165I).}

GARDINER states ${ }^{1}$ that this council consisted of forty-two members, the original number, forty-one, at which it stood in the first council, and again in the third, fourth, and fifth councils, being for this one election only increased by one. No explanation of the assumed increase of the council on this occasion or of the reversion to its original number at future elections has ever been given or suggested. As a matter of fact, the council when completed by the elections on 20 February $1649 / 50$ consisted of forty-one. On 12 February $^{2}$ the forty surviving members of the first council, one, the earl of Pembroke, having died since his election, were individually renominated, thirty-seven being chosen and three rejected, as Gardiner correctly states, and it was then resolved ' that -it be referred to a committee to consider of the best way of electing four persons more to be of the council of state for the year ensuing.' 3 On 14 February ${ }^{4}$ a motion that the election 'of four persons more' should be, as the report of the committee proposed, by ballot, was rejected by sixty-one to twenty-four (Hesilrigge being one of the tellers for the majority and Ludlow for the minority), and the report was recommitted.

On 16 February ${ }^{5}$ Colonel Morley brought up a fresh report as to the election of 'four persons to be of the council of state,' but on 19 February, it was decided that 'five persons ' should be chosen, ${ }^{6}$ and accordingly on 20 February five were chosen. ${ }^{7}$ But this did not bring up the number to forty-two as Gardiner inferred. For in the interim between the two elections (of the thirty-seven and the five respectively), an additional vacancy had arisen by the death of Alderman Wilson, one of the old council, who had been ro-elected on 12 February. Wilson is said by Professor Firth ${ }^{8}$ to have died on 19 February. In giving that date he has followed Smyth's Obituary, and I have myself, in reliance on their combined

1 History of Commonwealth and Protectorate, vol. i, cabinet edition, pp. 244, 245.

- In Gardiner the date is erroneously printed 11. The number was fined at forty one on 11 February, bat the election was deferred till the following day.

- Commons Jotrmals, vi. 368. + Ibid. 365. - Ibid. 967.

- Ibid. 868 .

' Ibid. 369. ' Dict. of Nat. Biogr., lxii. 132. 